\title{
Differentiated Access to Teaching: Teacher Recruitment Agencies and Flexible Work Arrangements
}

\author{
Katina Pollock \\ OISE/UT
}

\begin{abstract}
This paper explores the differential way in which employment practices utilized by Teacher Recruitment Agencies (TRAs) in England generate inequitable access to the teaching profession. Specifically, this paper critically examines the ways in which the present labour practices of TRAs impacts particular groups of women and marginalized people. The paper first describes the teacher recruitment agency phenomena, followed by an account of the feminist perspective that I use and the impact of educational reform on work arrangements. Next, I discuss flexible work and gender. Finally, I describe the place of foreign-born teachers and professional development issues in these new employment practices.
\end{abstract}

\begin{abstract}
Résumé
Cet article explore les différentes venues que les pratiques d'emploi utilisées par les agences de recrutement des enseignants (TRA) en Angleterre, pratiques qui engendrent un accès inéquitable à la profession des enseignants. Particulièrement cet article examine en critique les effets créés sur les groupes particuliers des femmes et des personnes marginalisées par les pratiques de travail de ces agences de recrutement. L'article décrit d'abord le phénomène de ces agences, suivi par le compte du point de vue féministe ulilisé par l'auteur, puis l'effet de la réforme de l'éducation sur les arrangements de travail. Ensuite, l'auteur discute le travail flexible et le sexe. En dernier lieu, l'auteur décrit la place tenue par les problèmes ayant trait aux enseignants étrangers en Angleterre et au développement professionnel dans ces nouvelles pratiques d' emploi .
\end{abstract}

My interest in acquiring access to the teaching profession began in 2000-2001 when I was collecting data for my master's thesis. During this time, I attended the launching of the Numeracy and Literacy Strategies for Key Stage 4 in England. At the morning session, I mentioned to the attendees at my table - which included representatives from five local secondary schools - that I was dissatisfied with my work arrangement in Canada and thinking about teaching in England. By the afternoon, three of the five schools' representatives - eager to recruit new teachers in a climate where it was not always easy to maintain a full complement of educators - had approached me with teaching employment offers. Initially flattered but somewhat overwhelmed, I began to consider my options. Eventually, I accepted a teaching position at one of the local secondary schools. 
While teaching in England, I was exposed to the private sector practice of providing teaching services to public education. As part of this practice, Teacher Recruitment Agencies (TRA) supplied teachers to schools. At the time, this was a novel idea for me. In comparing my own work arrangement to those who were employed through the private sector, I soon realized that one's social position one's gender, race, ethnicity, English as a first or other language, certification, prior teaching experience, residency, and cultural capital - influenced one's access to the teaching profession. As I became aware of this interplay, I considered the ways in which my own privileged position granted me access. I was privileged in multiple ways; I had prior teaching experience, I held a Masters degree that focused on understanding the implementation of the Numeracy and Literacy Strategy in the UK, and I was a woman who could teach Mathematics. Moreover, I spoke English with a particular accent that hinted at my Irish ancestry, and I had fair skin, red hair and blue eyes, dual citizenship, and UK cousins in the teaching profession who provided me with knowledge of the system that others did not have.

As a Canadian resident, I found myself in a community of "ex-pat" teachers - many of whom were employed through privatized teacher recruitment agencies - one of the fastest growing work arrangements. In observing many of my colleagues' employment situations, I realized that for certain groups of teachers, their work arrangement limited their opportunities for career advancement, professional development, and employment equity. These labour practices are part of what some refer to as the flexible work arrangements that are becoming so prevalent in many organizations, including school systems. Education reform initiatives have ushered in a number of changes in teachers' work practices and roles. Among other things, the teacher work force is becoming more differentiated; the core of the force has been downsized, while the periphery has increased in size and complexity. There is now a sizeable contingent work force of non-permanent teachers working in the system. What this means is that not everyone has the same access to the core teaching profession, that is, to fulltime work. Women, particularly those from other marginalized groups, are uniquely affected by these practices. Among other things, they encounter barriers to professional development and employment contracts that discourage stable work situations.

This paper explores the differential way in which employment practices utilized by recruitment agencies generates inequitable access to the teaching profession. Specifically, this paper critically examines the ways in which the present labour practices of TRAs impacts particular groups of women and marginalized people. The paper is organized in the following manner. First, it describes the teacher recruitment agency phenomena. This is followed by an account of the feminist perspective that I use and the impact of educational reform on work arrangements. Next, I discuss flexible work and gender. Finally, I describe the place of foreign-born teachers and professional development issues in these new employment practices. 


\section{Teacher Recruitment Agencies}

England's TRAs were originally established in response to the London teacher shortages in 1989 - 1990 (Barlin \& Hallgarten, 2001, p. 13). Teacher recruitment agencies, as private businesses, can operate in two ways; they can either introduce teachers to schools and let the Local Education Authority (LEA) or the governing body hire and pay teachers directly, or employ teachers to provide teaching service to public schools. In the latter case, teachers sign labour contracts with the recruitment agency and work for the agency - not the school. The agency, in turn, has a service contract to supply teachers to schools; the schools then pay the recruitment agency for the teaching service received. The services provided by the teacher recruitment agency can consist of a number of different arrangements. At one end of the spectrum, supply teachers can work on a daily arrangement; they are booked every day, regardless of the school site, wherever there is a demand. These teaching arrangements are usually neither subject specific nor grade specific. At the other end of the spectrum are teaching arrangements in which a school, through a recruitment agency, hires the teacher for a year or two to teach in a specific position. This post can be specific to a grade or subject within one school site.

In 1988, the introduction of Local Management of Schools (LMS) changed access to supply teaching. Supply teachers were no longer required to register with an LEA, but could now register with one or several agencies (Barlin \& Hallgarten, 2001). In keeping with the government's mandate of introducing the private sector into public education, TRAs emerged as the largest private sector proponents in public education. "In 1998-99, after transportation and Special Educational Needs (SEN) provisions, supply teaching made up the greatest proportion of single private sector involvement ${ }^{1}$ in publicly funded education with an estimated budgeted value of $£ 210$ million” (IPPR, 2001, p.12). While figures on spending for supply teachers varies according to source (Barlin \& Hallgarten, 2001), it has been estimated that in the late 1990s, schools spent more than $£ 600 \mathrm{~m}$ annually on supply teachers (Dean, 2001), approximately two thirds of which was from the private sector (DfES, 2001a; DfES 2001b). Another supply agency puts the figure at $£ 650 \mathrm{~m}$. Both estimates include long term supply teachers, which make up approximately half of the supply teachers provided by agencies (Barlin \& Hallgarten, 2001).

Non-permanent teaching such as occasional, supply, substitute, and relief teaching has become important for a number of reasons. First, changes in workforce practices are now encouraging the growth of a contingent teacher workforce in a number of Western countries. In Canada, 20\% of teachers work in occasional/supply positions (WALL, 2004). In England, between 1995 - 2001, it was estimated that the number of teachers engaging in supply work rose from 12,200 to 19,000 (DfEE, 2001a). Barlin and Hallgarten (2001) also estimate that approximately $10 \%$ of the teaching workforce is employed in either short-term or long-term supply roles.

Second, the issue of non-permanent teaching, until now, has "remained largely absent from educational agendas” (Galloway and Morrison, 1994). Barlin 
and Hallgarten (2001) state that the "DfES data give no official definitions or estimates of supply teachers" (p. 4). From an academic perspective, little is written within the literature on these work arrangements - particularly in the area of recruitment agency teaching (Menter, Muschamp, Nicholls, \& Ozga, 1997; Morrison, 1999a). The existing academic research is either written from an economic perspective (Dolton, 1996) where the industry is evaluated on "a simple economic measure of their [teacher recruitment agencies] capacity to meet demand" (Grimshaw, Earnshaw, \& Hebson, 2003, p. 268), or in conjunction with the larger, more general area of supply teaching (Coulthard \& Kyriacou, 2000; Morrison, 1999a). Educational issues pertaining to the non-permanent sector such as teaching quality, career commitment, and job satisfaction do not appear in the literature. Moreover, research from the 'teacher' perspective has not been investigated, nor does there seem to be an interest in exploring the impact of recruitment agency teaching on student performance.

Third, with government pressure to promote private sector involvement in education "little or nothing has been said about private sector supply agencies" (Barlin \& Hallgarten, 2001, p. 13) and their involvement in the teacher workforce. Recruitment agencies estimated that 40,000 "teachers worked in supply roles during 2001" (Grimshaw et al. 2003, p. 270) and "precise data on the levels of agency involvement do not exist" (p. 13). In England, data collection is even more difficult because recruitment agencies are less likely to share the information due to the competitive nature of the market (Barlin \& Hallgarten, 2001).

Fourth, the relationship between supply teachers and permanent teachers may not always be ideal for student learning. In considering the relationship between permanent teachers and the growing contingent of non-permanent teachers, "there is evidence to suggest that permanent teachers do not always react positively to their supply teacher colleagues...if this is so, the impact on the children caught in the middle is potentially significant, especially when one considers the number of supply teachers working" (Cornwall, 2004, p.18). Student achievement may also be compromised. As curriculum becomes more prescribed and accountable, and assessment systems become more elaborate with greater high stakes outcomes, a trend of increased professional development for permanent teachers can lead to an increase of absenteeism in the actual classroom. As a consequence, the use of occasional/supply teachers will increase (Tannenbaum, 2000). Not only will students experience increased teaching from occasional/supply teachers, but any lessons 'lost' during occasional/supply teacher work will become even more significant within the increased high stakes outcomes.

Fifth, changes in policies involving parental and/or family leave for permanent teachers also contributes to increased demand for occasional/supply teachers (Tannenbaum, 2000). Districts in the US such as the Community School of Frankfort, in Frankfort, Indiana, "indicate that the average teacher will miss ten days of school per year and that a child will spend one year of classroom time (K12) with substitute teachers" (Long 1996). Nationally, in the US "on any given day, substitute teachers filled 10 percent of the nation's classrooms” (Friedman, 
1983) and "the typical student [will] spend seven days of every school year, or approximately 84 days during 12 years of schooling, with a substitute teacher" (McIntire \& Huges, 1982). In Canada, it has been recently reported that on average, teachers are absent 10 working days within an academic school year; in Ontario it is higher with an average of 12 days (Denley, 2005). Lastly, there is limited literature that takes into account inequities related to TRA practices.

\section{A Feminist Perspective}

Understanding the phenomenon of access to the teaching profession reinforces the need to explore the role of marginalization and gender. One way to do this is through a feminist perspective. My analysis is derived from a critical feminist perspective, contextualized within a framework of both a feminized and flexible workforce. A feminist lens (Woodward, 1997) acknowledges both the "interlocking relation of economy and family and of class and gender" (Seidman, 1998, p. 259) and the belief that 'woman' is comprised of a multiplicity of identities, which are "permanently open to contestation and to new social and political deployments" (p. 272). A feminist position emphasizes the unequal power relationships not only in the gender arena, but also with respect to other systemic phenomena like class, race, ethnicity and sexual orientation. Thus, it is not easy to speak for all women because of the diversity of women as a group and the particularities of each woman's situation. Acker (1999) reminds us that:

women are not all alike, but vary according to race, ethnicity, sexuality, marital status, age, dis/ability, and in many other ways...the difficulty lies in the extent to which we can make meaningful generalizations about women teachers, when they are so diverse. Work on women in teaching, like feminist studies generally, must struggle with these challenges. (p. 25)

Whatever the case, in the current global economy, employment practices and work environments benefit some female teachers and disadvantage others. This disadvantage is based on class, gender, race and ethnicity.

A feminist perspective recognizes that the current increase of women in the workforce is more than a numerical phenomenon. It also admits that this change is accompanied by differences in power and opportunities. For example, Michael Apple's (1989) conception of feminized education states that once an occupation is feminized, the work associated with the occupation changes. A feminized occupation is not merely considered feminized when more women are actively working in the profession. Rather, feminization occurs when the work, originally done mostly by men, is now done by women. Women, however, find themselves in positions that are less autonomous and deskilled. These positions provide reduced opportunity for upward mobility, lost wages, and greater pressure for rationalization (Blackmore, 1997; Dillabough, 1999). Perceived through alternative employment arrangements, teachers' work is considered mere technical labour (Bascia \& Hargreaves, 2000), rather than of skills worthy of a professional status (Lortie, 1975). 
Another way of understanding the feminization of education is by looking at it in terms of societal processes of production and reproduction. Martin (2001) makes a distinction between the societal processes of production and reproduction with regard to gender when she states that

...reproductive processes include not simply the biological reproduction of the species, but the rearing of children to maturity and the related activities of keeping house, managing a household, and serving the needs and purposes of family members. In turn, the productive processes include political, social, and cultural activities as well as economic ones. (p. 73)

The reproductive processes have now become a part of the differentiated, contingent workforce. Where once they were associated more with the private world of home, these reproductive process have become part of the public world of business, politics and culture. This is true of education systems as well. Teachers on the periphery - supply teachers - step in and cover when regular permanent teachers are absent. These processes of 'filling in' have been defined in the literature as 'baby-sitting' - a nurturing term (Shepherd, 1997, Abdal-Haqq, 1997; Weems, 2003). But from the standpoint of economic value, the process of production has been, and arguably remains, valued more than the reproduction process. Martin (2001) supports this belief when she writes:

One of the most important findings of contemporary scholarship is that our culture embraces a hierarchy of values that places the productive processes of society and their associated traits above society's reproductive processes and the associated traits of care and nurturance. (p. 77)

A feminist position helps us understand how the new contingent workforce, composed mostly of women, has fewer opportunities to access what the teaching profession has to offer. The process is particularly evident in teacher recruitment, in part, a product of educational reform.

\section{Education Reform}

In order to understand teacher recruitment agency practices and their impact on differentiation, we need to explore recent educational reform and its' relationship to the economy. Recent education reforms have attempted to tightly couple education and the economy in an effort to create economic stability and/or to encourage growth. They have been engineered to control the skills and knowledge that individuals gain through formal education to allow a new workforce to emerge. The idea is that this new workforce would be responsive to the needs of a nation's successful competition in the global market. The New Labour Government in the UK has followed this model. As documented in Schools: Building on Success (2001c):

Education is a recognized priority, not just for Government, but also for society as a whole. It is seen not only as key to developing equality of opportunity, but also to enabling the nation to prepare for the emergence 
of the new economy and its increased demands for skills and human capital (p. 8).

In an attempt to be globally competitive, yet reduce public spending, the English government sought to encourage private industry to enter the education sector. This promotion occurred at all levels of government: from the national level to the actual school site. Measures such as the introduction of the Skills Council and the extension of the Private Finance Initiative (PFI) were just two of the ways in which the role of business in education was strengthened (Hill, 1999).

In order for privatization to be successfully introduced, the structure of schooling had to change. These changes entailed two complementary processes of control. The first involved explicit control of educational curriculum and pedagogy. For example, England introduced the Standard Curriculum and the National Literacy and Numeracy Strategies (NLNS). Coinciding with this centralization trend was the implementation of elaborate outcomes based accountability systems. Control over curriculum and delivery alone, however, does not guarantee that these 'new' skills and knowledge will be taught/learned by the potential new workforce.

A second form of control occurred through a decentralization process aimed at those who have been the traditional gatekeepers for curriculum and delivery - LEAs, the teaching profession, and unions. As Goodson and Hargreaves (1996) remind us "control of the teaching force had always been seen as an important state objective" (p. 21). Grace (in Goodson and Hargreaves, 1996). also reminds us that teachers have long been regarded as 'crucial agents in the structuring of popular consciousness,' while Goodson and Hargreaves (1996, p. 21) contend that they, "are therefore able to support or threaten the existing social order" (Goodson and Hargreaves, 1996, p. 21). The second strategy of recent educational reform was to reduce or eliminate the traditional gatekeepers of curriculum and pedagogy from their original power and autonomy; England's reforms' have had a "preoccupation with regulation of producers-teachers, local government officers and central government officials" (Menter, Muschamp, Nicholls, \& Ozga et. al., 1997, p.25). The introduction of site-based management of schools, for example, could be considered an attempt to take power away from LEAs and bust unions - the very organizations that would be in a position to object to this differentiation.

\section{Changes in Work Arrangement.}

Changes in work arrangements have accentuated a differentiated workforce. Differentiation in the workforce reflects post-/neo-Fordist practices (Blackmore, 1999, Harvey, 2000) such as flexible work arrangements that often tend to be nontraditional. Some refer to these non-traditional work arrangements and changing work environments as the "New Work Order". The new work order occurs in many work sectors, a product of a "growing alignment between the business world in the new capitalism and various non-business spheres of interest, including school and academic disciplines promoting school reform efforts” (Gee, 
Haul \& Lankshear, 1996, p. 49). It is divided into a core group and two periphery groups. The core group consists of traditional full-time, permanent workers who experience job security, promotion opportunities, professional development, and pension and other benefits. The first of the two peripheral groups has full-time employment but is less skilled, has less access to career opportunities, and exhibits a high labour turnover. The second peripheral group consists of "part-timers, casuals, and fixed term staff, temporaries, sub-contractors and public subsidy trainees, [and has] even less job security than the first peripheral group" (Harvey, 2000 p. 150). Recent employment practices in teaching reflect this model. Soucek (1994), for example, describes a three-tiered, differentially-skilled, hierarchical teacher workforce as "highly skilled professional workers, specifically skilled peripheral full-time workers, and generically-skilled peripheral part time or casual workers” (p. 55). Peripheral workers in teaching include teachers who work at supply teaching (Morrison, 1999a, 1999b), those under enterprise bargaining arrangements ${ }^{2}$, part-time teachers (Young, 2002; Young \& Grieve, 1996) and in the case of this paper, recruitment agency teachers (Barlin \& Hallgarten, 2001; Grimshaw et al., 2003; Johnson, 2001).

Gee, Haul \& Lankshear (1996) argue that the new work order attempts to create new social identities including "new leaders, new workers, new students, new teachers, new citizens, [and] new communities" (p. xiii). "New" employees, in this case refer to new teachers who can experience easy access to teaching positions. These employment opportunities, however, differ from the work arrangements of core teachers. For example, new daily periphery workers do not do lesson plans, marking, service and committee work, nor do they have the opportunity to take part in professional development or community related activities. As a consequence, these 'new' teachers' loyalty tends to rest with the profession and not with the individual school or community. In contrast, teachers who represent the 'core' - full-time, permanent, teacher - still have some degree of benefits, such as tenure, health insurance and pensions and tend to have more traditional, more highly valued and respected teaching experiences.

The decentralization processes associated with education reform has contributed to a differentiated workforce. Full-time permanent teachers tend to be somewhat isolated from teachers in non-traditional work arrangements on the periphery. At the school site, teachers' interactions generally tend to occur either with repeated contact in the staff room, at school-organized meetings, or through professional development sessions - situations where few TRA teachers would be present. This lack of interaction between teachers promotes a workforce division where core teachers tend to misunderstand the work of colleagues on the periphery. Many schools in England have teachers holding similar work assignments, such as full-time permanent and long-term recruitment, yet they are perceived to be doing different work. This promotes a working environment that can be less collegial. In some cases, it generates a more pronounced hierarchy within the labour force (Blackmore, 1999). This hierarchical workforce often consists of recruitment agency teachers who are less valued than full-time, 
subject-specific, permanent teachers. This labour hierarchy is reinforced with the increasing employment of a flexible workplace.

\section{The Contingent Workforce and the Flexible Firm}

A differentiated work structure and a contingent workforce are symbiotic. In order for a contingent workforce to thrive, it requires a differentiated work structure. Conversely, a differentiated work structure can work well with a contingent workforce. By contingent work I mean "any job in which an individual does not have an explicit or implicit contract for long-term employment” (Polivka in Bjorkquist \& Kleinhesselink 1999). In England, many teachers do not have long-term employment contracts. According to the DfEE (2001c):

...in 1985, in the maintained schools sector in England the FTE of parttime teachers in schools was 16,300. Ten years later that number increased to 28,700 (headcount 60,700) and in the five years since (2000 figures) has jumped to 33,300 (headcount 72,200) (DfEE, 2000a). 24,300 of these were on fixed term contracts” Barlin \& Hallgarten (2001).

This movement away from full-time work to other types of employment such as part-time work reflects general labor market trends and post-/neo-Fordist practices. Robinson (1999) points out that in "the UK between 1979 and 1997, the percentage of workforce in full-time, permanent employment dropped from about seventy five percent to sixty two percent across all sectors of the labour market" (p. 9). The movement to contingent workforces sets the stage for the "flexible firm” labour practices.

Some describe the flexible firm as an arrangement that best reflects labour practices in Westernized economies (Atkinson, 1984). The flexible firm generally consists of three practices: 1 ) functional flexibility where employees are deployed quickly and easily over a number of activities and tasks; 2) numerical flexibility where employers can take on or discard workers as demand requires;

and 3) financial flexibility where costs reflect the supply and demand of the labour market and remuneration systems enhance the two previous flexibilities (Atkinson, 1984).

Functional flexibility in education requires employment arrangements that allow hiring and deployment of teachers across a number of activities. Moreover, teachers' tasks and skills must be transferable to a number of different work environments. The assumption that teaching skills are highly transferable is predicated on the concept of teaching as technical labour (Bascia \& Hargreaves, 2000), the functionalist belief that students and their needs are essentially uniform (Darling-Hammond, 1994), and the idea that as long as "procedures are correctly defined, clearly detailed, and carefully monitored, most major teaching decisions can and should be prescribed through policy mandate that alter school schedules, programs, assessment and teaching responsibilities” (Bascia \& Hargreaves, 2000, p. 5). The concept of teaching as technical labour also suggests that teaching does not require professional development but rather simple skill-sets that may be 
acquired by anyone. De-professionalization combined with alternative employment practices allow for numerical flexibility.

Numerical flexibility is aided by the TRA structure. TRAs capitalize on the idea of transferability and teaching as technical labour. While a few TRAs market themselves as having teachers with experience, particular training, or subject specialties such as Maths, French or special education, many others adopt post-Fordist/neo-Fordist practices. In the latter situation, teachers are considered to have basic technical skills that can be transferred across most grade levels and subject areas; they can be easily deployed across the education system. With an arsenal of teachers on the roster ready for teaching, TRAs provide the opportunity for easy employment and, because of contractual arrangements, release when the service (teacher for teaching) is no longer needed. Lastly, as witnessed in the court ruling between Time Plan Education Group Ltd. $v$ The National Union of teachers and Another (14 June 1995) (Morrison, 1999a), TRAs are under no obligation to pay their employees (teachers) the same rate of pay as teachers employed in the public sector.

Financial inequities in pay and benefits exist for teachers who work through TRAs. Agency teachers can feel these inequities in both the short-term and long-term. As stated earlier, recruitment agency teachers do not receive the same terms and conditions as traditional school teachers as defined under the School Teachers' Pay and Conditions Act 1991 because they are not employed by the LEA or the school governors (Grimshaw et al., 2003). Initially the lack of regulation benefited supply teachers, many of which realized their market worth, and were in the beginning negotiating their school preferences and salaries. But as the market demand changed the ability to negotiate disappeared. Teachers who work for teacher recruitment agencies are not entitled to "join the teacher's pension scheme and nor can they currently claim parity in contractual terms and conditions with their directly employed colleagues" (Grimshaw et al., 2003, p. 280). These differences in financial equity reflect the differentiated workforce practices found in other work sectors. At the local level or industry level, recruitment agency teachers have limited power within their agencies because there are few regulations governing their work and work relationships. Therefore, these teachers are at the mercy of agencies who determine their pay scale; so within the teacher recruitment work, teachers are subject to receiving variable daily rates (Mansell 2000; Clancy, 2002; Willis in Barlin \& Hallgarten, 2001). This pay deferential reflects the financial flexibility characteristic of the flexible firm.

There is a difference, however, between a flexible workforce and a flexible workplace. Young (1999, p. 140) makes the distinction:

A flexible workforce reflects employers' efforts to increase staffing flexibility and lower their fixed staffing costs as an organizational response to the pressures of financial restraint and escalating competitiveness. This is market-driven, "causal" employment in which employees have little influence on the conditions of their employment.... A flexible workplace, however, reflects greater societal acceptance that there should be 
opportunities for a range of optional employment arrangements that do not necessarily involve standard, full-time employment. Such arrangements afford individual employees more flexibility to tailor their paid work arrangements to complement other dimensions of their lives, because they have some control, or at least influence, over their lives, because they have some control.

TRAs operate under flexible workforce approach. Many recruitment agency teachers initially are attracted to the TRA work arrangement with hopes of capitalizing on the flexible workplace idea. Unfortunately, many find that that the promised flexibility does not live up to their expectations; the salary and limited benefits do not allow them to utilize the flexibility and they have to work as much as possible to make ends meet. For example, the holiday periods throughout the school year are difficult to manage because they are not paid at this time. This is significant in England for teachers experience a holiday period on average every seven to eight weeks. Grimshaw and his colleagues (2003) noted this in their study of TRA supply teachers. They indicate that:

Pressures to maximize earnings means that many of the supply teachers we spoke with simply could not afford to take advantage of the potential flexibility offered by supply work. In particular, everyone we spoke with found the unpaid school holidays very difficult to manage and it was this rather than other rights such as pensions that was cited as the main negative aspect of supply teaching. (p. 280)

The idea of a flexible workplace implies that teachers will have more control over when and where they work. Unfortunately, flexibility over work location also has its limitations. The economization of education saw schools participate in capital practices where wealth secured the needs of individual schools. With a freer market in hiring teachers, schools that had more wealth tended to be the 'ideal' schools to teach in and also tended to have less teacher turnover, meaning less demand for supply teachers. Disadvantaged schools struggled to provide a full staff. Therefore the use of teacher recruitment agencies was more prevalent in less ideal teaching situations. With the movement to school site-based management coupled with high staff turn over and limited budget for hiring teachers (Galloway and Morrison, 1994), teachers had become a "source of cost within the 'enterprise', rather than a method of adding value to the 'product'” (Menter et al., 1997, p. 65).

\section{Maintaining a Differentiated Workforce.}

Many TRAs have developed contractual arrangements that maintain a differentiated workforce. Since teacher recruitment agencies predominantly focus on providing services for short-term, long-term and part-time teaching positions, it is in their best interest to discourage schools from permanently hiring recruitment agency teachers. Initially, teachers hired by schools on a permanent contract create a loss of income for the agencies. Recruitment agency contracts such as the 
LOCUM GROUP Education Recruitment (n.d.) illustrate clauses that are meant to protect the interest of the TRA enterprise:

33.1 The Supply Teacher accepts on the understanding that he/she will work in that post through the Agency. If a Supply Teacher accepts any such post, or any part thereof, or any extension of that post through any another agency he/she will be liable to recompense the Agency immediately, upon demand, for any losses that the Agency may suffer as a consequence of this action.

33.2 The Supply Teacher shall immediately inform the Agency if he/she is offered a permanent or temporary appointment with any client as a result of being introduced to any client by the Agency.

From a business perspective, it is logical that recruitment agencies be compensated for any loss of income when one of their staff has been hired for a permanent teaching position. But the repercussions of this type of contract imply that many schools would not consider a recruitment agency teacher for a full-time teaching position. This occurs for a number of reasons. First, recruitment agency teachers often cannot afford to compensate the agency for the lost income and are, in turn, trapped into staying with the agency. Many schools attempt to pay the agencies on behalf of the teacher but have found it financially taxing. Upon paying off the recruitment agency, the school is then faced with having to pay the teacher a higher salary because the teachers will now fall under the legislated School Teachers' Pay and Conditions Act 1991, which guarantees a substantially higher fee than that initially paid to the recruitment agency. So some schools maintain an unofficial policy of not seeking recruitment agency teachers for permanent positions. This gave rise to a vicious cycle of needing permanent teachers, but not being able to afford to hire them. Consequently, classrooms were filled with recruitment agency teachers. The unofficial practice for a teacher interested in a permanent teacher contract was to leave the supply agency to seek employment independently. This was a risk that many agency supply teachers could not afford to take, particularly those who were dependant on supply work as a major source of income.

The pattern of less autonomy, reduced authority from deprofessionalization, reduced pay, limited voice and job security also points to a feminization of the contingent workforce. This feminization, not surprisingly, coincided with increased numbers of women in the workforce over the past few decades (Blackmore, 2000). More importantly "the increase of women in the workforce has acted as a major catalyst for the[se] labour market trends of contingent work” (Barlin \& Hallgarten, 2001, p. 10). 


\section{Gender and the Contingent Teacher Workforce.}

Participation of women in the global workforce, particularly education, has increased (Ball, 1998; Harvey, 2000); Young, 1999, and OECD, 2001). Policy changes related to privatization, competition and selection in England, as well as changes in the teaching workforce, encourage this feminization (Barlin \& Hallgarten, 2001). At a glance, it could be argued that this increase of women in the employment sector is a positive step. Supposedly, women now have access to equal opportunities if we accept Betty Friedman's belief that "work outside the home...[is] the key to liberation" (hooks, 1984, p. 95). Depending on one’s social positioning, employment through a TRA may signify some form of liberation. But for the vast majority of women it does not. The increase of women in alternative work arrangements does not necessarily mean full access to the teaching profession. Many female teachers entering the profession through TRAs can work in a teaching post next to a full-time permanent teacher and receive different pay, less professional development and not be entitled to any preparation time.

At the same time as the number of women working in this differentiated workforce increased, the welfare state - where women were traditionally the beneficiaries of it in their capacities as employees and welfare recipients - was disappearing (Blackmore, 1999). The welfare state provided space for women to enter the workforce on equal footing. As the welfare state disappeared, the supports and spaces that originally allowed women competitive access to the workforce were reduced and new forms of work arrangements - particularly those on the periphery - were increased. If we look at this from a core-periphery perspective we see that historically (and currently today) men predominantly held positions that were at the core while women mostly held positions on the periphery. As the labour arrangements changed, much of the core was (is) protected while the spaces and supports created for women to enter the core were dismantled, denying women access and relegating them to predominantly working at the periphery. The consequence was that women's relationship with the workforce changed from one of more equitable access to one of limited access (Blackmore, 1999) For instance, Galloway and Morrison (1994) point out how "In 1993 GEST [Grants for Education Support and Training] funding for women returners to teaching ceased, such schemes being perceived as less of a priority since teacher shortages appeared in the short-term to have eased” (p. 3). What has not been addressed is how this financial support assisted women teachers back into the teaching workforce regardless of the teacher supply and demand. The initiative was not perceived as an equity practice and therefore dismissed on economic grounds, ignoring the social implications. Harvey (2000) makes a connection between the loss of the welfare state and the resurgence of patriarchal practices and exploitation of women,

...not only do the new labour market structures make it much easier to exploit the labour of women on a part-time basis, and so to substitute lower-paid female labour for that of more highly paid and less easily laid-off core male workers, but the revival of sub-contracting and domestic family labour systems. (p. 153) 
As the state withdrew support, opportunities and assistance, its relationship to the population of women altered; we see what Blackmore (1999) describes as a shift from the welfare state to the contractualist state. Larger numbers of women in the workforce coincided with cuts to government social programs and services, placing responsibility, in most cases, on women who were left to do more caring work (Blackmore, 1999). Research into women teachers and their prevalent 'existential identities' (Casey, 1992, p. 206) indicates that their role as teacher and care provider extends beyond the classroom to areas of mothering, caring, providing for others, activism, etc. In most of these roles, there was a financial obligation that forced these teachers to seek work; they had a direct need to meet their 'other' obligations. Many women were seeking work with a particular structure that allowed them to meet their additional responsibilities. Barlin \& Hallgarten (2001) pointed out that in England, working mothers were one of the primary beneficiaries of supply work.

Not all women experience the flexible workplace in the same way. Privileged women, whose primary income is not dependant on supply teaching may choose to take advantage of the promoted flexible workplace idea. However, many other women find themselves seeking as much supply teaching as possible in order to meet their financial obligations. This tends to hold true for women who come to England from overseas countries.

\section{Taking Advantage of Foreign-Born Teachers}

TRAs take advantage of permeable borders; many of them actually recruit teachers from other countries (Wallace 2004). This is necessary for some because many native UK teachers refuse to work in less than ideal teaching posts (Grimshaw et al., 2003; Menter \& Hutchings, 2004). It is these types of 'hard-tofill' positions that also encourage TRA services. Often it is overseas teachers that occupy these positions. For instance, Morrison's (1999a) research captured this attitude towards particular teaching posts when she reported "Many schools have actually preferred overseas supply teachers because 'even in the toughest schools ...their attitude is 'right, let's get on with it', not walking out within ten minutes saying 'I'm not teaching them"' (p. 179).

The above statement speaks to the challenges that some overseas teachers face once they begin work in England. Many overseas teachers hold holiday work permits or specific teaching permits and cannot afford to refuse work. In addition, many teachers new to England have not established networks which allow them to find either teaching work or other means of work; therefore they keep teaching. Many teach in England and send portions of their reduced wages to family or their home community (Ghosh, 2006).

TRAs have indicated, in the past, that they need to recruit overseas as it is difficult to maintain a sufficient employee base for their service (Menter \& Hutchings, 2004). Changes in immigration policies encourage overseas recruitment. As recruitment agencies attempt to keep a healthy supply of teachers ready to teach at any point in time, they have reported recruiting teachers from other countries. For instance, in 2000 approximately 10,000 were brought to 
England from overseas. One agency alone recruited 2,000 supply teachers that year (Barlin \& Hallgarten, 2001, p. 8).

This migration of teachers has contributed to a number of growing issues (Goldring, 2001). Barlin \& Hallgarten, (2001) contend that teacher mobility and recruitment has become an international phenomenon. For example, "New York recruits in Austria and Chicago in Egypt. Holland recruits in Germany. England recruits in Australia, New Zealand and South Africa (Sikkes, 2001.) More recently, some agencies in England have now started to recruit in India, the Philippines and the US” (p. 8).

What is not widely known is that teacher migration has had a negative impact on some countries (Batty, 2003). For instance, Kader Asmal, a former South African Education Minister, had officially requested that English schools stop luring their top qualified teachers (Smithers \& McGreal, 2001), stating that 'such raids on the teaching profession at a critical time in our history [was] not helpful for the development of education in South Africa' (Elliott and Robbins, 2001). These practices were facilitated by recent legislation that eased the employment criteria for overseas teachers; it promoted rather then deterred the recruitment, complicating the issue in other countries (Ballinger in Barlin \& Hallgarten, 2001, p. 9).

At one point, TRAs had control over their employees work visa applications. They were originally able to apply for work permits for overseas teachers (Spencer, 2002). Further investigation into the unregulated TRA workforce indicated, at the time, that recruitment agencies were applying for work visas at a disproportionate rate (Shaw, 2002). This created a situation where many relocated teachers found that there was no suitable work available or that they were not suited for the job. This international recruitment trend at times presented situations where relocated educators experienced class discrimination, racism and language barriers when they came to work in England (Crace, 2003; Shaw, 2002). Many of these foreigners were women from under-developed countries, whose first language was not English and many lacked the cultural capital to navigate the English bureaucratic systems. Consequently, many found themselves a part of the social security system in England that left them with no way of supporting themselves nor any means to return home (Crace, 2003; Shaw, 2002).

Morrison (1999a) describes how the 'historical' tendency for agencies to exploit and abuse labour has caused agencies to attempt to improve their image through promoting the rhetoric of 'professionalism'. She maintains that they constructed their version of professionalism by voluntarily following The Code of Good Recruitment Practice from the Federation of Recruitment and Employment Services (FRES). But these were codes of conduct for good economical recruitment agency practices, not for educational practices of teachers working for recruitment agencies or for the employers providing the educational service. Most importantly, "the DfEE [did] not approve or accredit employment agencies, nor keep a register of those who follow the advice on good practice set out in the guidelines notes [Guidance Notes for Teacher Employment Business and Agencies and on the Use of Supply Teachers] (DfEE, 1996, p.10). The English 
government only considered intervening in the issuing of work visas when it was pointed out that a number of recruitment agencies were bringing teachers to England without a placement and not finding them work (Shaw, 2002).

The sensational case of the Canadian recruitment agency teacher, Amy Gehring, increased public pressure forcing government to attempt some regulation of the industry (Grimshaw et al., 2003). Ms. Gehring was accused of having sex with two of her 15-year old students at a party and also admitted to sexual relations with students at her previous school. Key to this case was the legal question of who was responsible for overseeing Ms. Gehring's conduct - the agency that hired Ms. Gehring or the school at which she taught.

The recruitment practices of TRAs generated conditions that exasperated the differences among groups of teachers. This in turn led to less than ideal supports for some teachers. Among other things, TRA teachers at the time had limited access to professional development activities.

\section{Professional Development.}

Recruitment agency teachers - often finding themselves in the most demanding teaching situations - were often not provided professional development and supports needed to teach effectively in demanding schools environments. TRA assignments are often taxing both emotionally and physically. Because TRA teachers and permanent teachers are not regulated by the same government regulations, TRA teachers are not required to participate in professional development that is mandatory for regular teachers. Initially, this aspect of supply teaching may have been appealing for some because there was less time commitment and responsibility (Grimshaw et al., 2003). But professional development is necessary, in order for all teachers, including TRA teachers, to be successful with the prescribed standard curriculum. For instance, the standardization of curriculum and the implementation of the National Literacy and National Numeracy strategies (NLNS) are very complex, so all teachers need support. Galloway and Morrison (1994), for example suggest that "supply teachers need to be professionally up-to-date as much as those they replace, and their working situations call for high classroom management skills” (p. 3).

Because supply teachers are not required nor encouraged to participate in professional development, many have limited opportunities for skills and knowledge training. This, despite the fact that their teaching quality was believed to be ineffective (Johnson, 2001). This lack of opportunity for professional development acted as a barrier to teachers who wanted to progress upward through England's hierarchical educational system. This is especially true for teachers recruited overseas as many required additional support to teach within England's cultural and social context.

\section{Conclusion.}

Contingent, flexible work structures that are common to many work sectors have now found their way into educational institutions. In England, for example, 
teacher recruitment agencies employ these arrangements. The consequences of these practices, however, are not always positive. Among other things, these flexible structures restrict access to the teaching profession. For example, overseas teachers who journey to England seeking employment as a means of career development and a better way of life - many of them women - may initially find easier access to teaching through TRA employment. However, many then find themselves trapped in TRA contractual arrangements that offer little professional development, support for less than ideal teaching situations, and mobility within the teacher hierarchy. The bottom line here, though, is that these work arrangements will inevitably have an impact on student learning. The increasing numbers of teachers who have only non-permanent contracts - whether they are part of TRAs or not - will not be equipped to meet the many challenges required of contemporary teachers. If policy makers and educators are to provide the best possible learning opportunities for all students, then they will have to think carefully about the opportunities that they provide for the entire teacher workforce. Providing optimal learning environments may even require that they actively resist the growing trend towards flexible, contingent workforces.

\section{Notes:}

1. Payroll, Finance and Personnel combined totalled £350m, but separately each factor is assumed to be less than supply teaching total.

2. In Australia, teachers in some states contract individually at the school level. In many of these situations, the individually arranged contracts result in teaching contracts with lower pay, less job security, and reduced benefits.

\section{References}

Abdal-Haqq, I. (1997). Not just a warm body: changing images of the substitute teacher. Washington, DC: ERIC Clearinghouse on Teaching and Teacher Education.

Acker, S. (1999). The realities of teachers' work: Never a dull moment. London: Cassell.

Apple, M. (1986). Teachers and texts: A political economy of class \& gender relations in education. New York: Routledge.

Atkinson, R., D. (1984). Flexibility, uncertainty and manpower management. Brighton: Institute of Manpower Studies.

Ball, S. J. (1998). Big policies/small world: An introduction to international perspectives in education policy. Comparative Education, 34(2), 119-128.

Barlin, D., \& Hallgarten, J. (2001). Supply teachers: Symptom of the problem or part of the solution? Retrieved from http://www.ippr.org/articles/index.php?article=26; 
October 28, 2005.

Bascia, N., \& Hargreaves, A. (2000). Teaching and leading on the sharp edge or change. In N. Bascia \& A. Hargreaves (Eds.), The sharp edge of change: Teaching, leading and realities of reform. New York: Routledge/falmer.

Batty, D. (2003, Mar 11, 2003). Draining the south: Britain's public services are increasingly reliant on foreign workers, but the knock-on effect has been staff shortages in poorer countries. The Guardian, pp. 21-24.

Bjorkquist D. C., \& Kleinhesselink, J. (1999). Contingent employment and alienated workers. Journal of Industrial Teacher Education 36(2), 5-23.

Blackmore, J. (1997). Level playing field? Feminist observations on global/local articulations of the re-gendering and restructuring of educational work. International Review of Education, 43(5-6), 439-461.

Blackmore, J. (1999). Localization/globalization and the midwife state: Strategic dilemmas for state feminism in education? Journal of Education Policy, 14(1), 33-54.

Blackmore, J. (2000). Warning signals or dangerous opportunities? Globalization, gender, and educational policy shifts. Educational Theory, 50(4), 467-486.

Casey, K. (1992). Why do progressive women activists leave teaching? Theory, methodology and politics in life-history research. In I. F. Goodson (Ed.), Studying Teachers' Lives. New York: Teachers College Press.

Clancy, J. (2002). Teacher to undercut supply agencies. Retrieved November 2, 2002, from http://www.tes.co.uk

Coulthard, M., \& Kyriacou, C. (2000). Solving the teacher recruitment crisis. Education Today, 50(2), 21-27.

Crace, J. (2003, Jan 28, 2003). Education: "My family in Africa send me money to get by": As Britain struggles to recruit teachers. The Guardian.

Cromwell, G. (2004). A view from across the pond: Exploring the perceptions of supply (substitute) teachers in England. Subjournal, 5(1), 9-17.

Darling-Hammond, L. (1994). Who will speak for the children? Phi Delta Kappan, 76(1), 21-35.

Dean C (2001) 'Hire staff and win a toaster' The Times Educational Supplement 8(6).

Denley, R. (2006, July 18). Time to tackle absent teachers. The Ottawa Citizen, pp. C1, C3.

DfEE. (1996). Guidance notes for teacher employment businesses and agencies. London: London Teacher Supply, Training and Qualifications Division.

DfEE. (2001a). Statistics of education. Education and training expendure since 1991-92

(No. 07/01). London: National Statistics Bulletin.

DfEE. (2001c). Schools: Building on success: Department for Education and Economy.

DfES. (2001b). Statistics of education. Education and training expendure since 1991-92 (No. 07/01). London: National Statistics Bulletin.

Dillabough, J.-A. (1999). Gender politics and conceptions for the modern teacher: Women, identity and professionalism. British Journal of Sociology of Education, 20(3), 373-394.

Dolton, P. (1996). Modelling the labour market for teachers: Some lessons from the UK. Education Economics, 4(2), 187-205.

Elliott and Robbins (2001) 'Stealing' of teachers stirs anger abroad”' The Sunday Times 25(2).

Friedman, D. J. (1983). High school substituting: Task demands and adaptations in educational work. Urban Education, 18(1), 114-126.

Galloway, S., \& Morrison, M. (1994). The supply story: Professional substitutes in education. London: Falmer Press.

68 Canadian and International Education Vol. 36 no 2 - October 2007 
Garner, R. (2001, August 6, 2001). Council sets up teacher agency as supply costs soar. The Independent.

Gee, J. P., Haul, G., \& Lankshear, C. (1996). The new work order: Behind the language of the new capitalism. St. Leonards, NSW: Allen \& Urwin.

Ghosh, B. (2006). Migrants' remittances and development: Myths, rhetoric and realities. Den Haag, The Netherlands: International Organization for Migration.

Goldring, M. (2001, August 31, 2001). Hire education. The Guardian.

Goodson, I. F., \& Hargreaves, A. (Eds.). (1996). Teachers' professional lives (Vol. 3). London: Falmer Press.

Grimshaw, D., Earnshaw, J., \& Hebson, G. (2003). Private sector provision of supply teachers: A case of legal swings and professional roundabouts. Journal of Education Policy, 18(3), 267-285.

Harvey, D. (2000). The condition of postmodernity. Malden: MA: Blackwell Publishers.

Hill, D. (1999, September). 'Education, education, education', or 'Business, business, business'? The third way ideology of New Labour's educational policy in England and Wales. Paper presented at The European Conference on Educational Research, Lahti, Finland.

hooks, b. (1984). Feminist theory from margin to center. Boston: South End Press.

Institute for Public Policy Research (IPPR). (2001). Building Better Partnerships. London: Author.

Johnson, M. (2001). Making teacher supply boom-proof. In M. Johnson \& J. Hallgarten (Eds.), From victims of change to agents of change: The future of the teacher profession. London: Central Books.

LOCUM GROUP education group. (n.d.). The terms of the commission agreement between the agent and the client and terms of the provision of supply teaching services by the supply teacher to the client. Freeport, Ilford, Essex..UK: LOCUM GROUP.

Long, A. (1996, Oct 15). EduTemp Training session. Paper presented at the substitute teacher training seminar: The community school of Frankfort, Indianapolis, Frankfort, Indiana, Sr. High School.

Lortie, D. (1975). Schoolteacher: A sociological study. Chicago: The University of Chicago Press.

Mansell, W. (2000). Agency cuts pay for supply staff. Retrieved November 2, 2002, from http://www.tes.co.uk

Martin, J. R. (2001). Becoming educated: A journey of alienation or integration? Calgary: AB Detselig.

McIntire, R., \& Hughes, I. (1982). Houston program trains effective substitutes. Phi Delta Kappan, 63(702).

Menter, I., \& Hutchings, M. (2004, February 06). Too valuable to waste. Teachers Education Supplement.

Menter, I., Hutchings, M., \& Ross, A. (2002). The crisis in teacher supply. Stoke on Trent, UK: Trentham Books.

Menter, I., Muschamp, Y., Nicholls, P., \& Ozga, J. (1997). Work and identity in the primary school: A post-Fordist analysis. Birmingham: Open University Press.

Morrison, M. (1999a). Temps in teaching: The role of private employment agencies in a changing labour market for teachers. Journal of Education Policy, 14(2), 167184.

Morrison, M. (1999b). Running for cover: Substitute teaching and the secondary curriculum.

OECD. (2001). Education at a glance: OECD indicators. Paris: OECD. 
Robinson (1999) 'Explaining the relationship between flexible employment and labour market regulation' in Felstead and Jewson Global Trends in Flexible Labour Macmillan Press: London

Seidman, S. (1998). Contested Knowledge. Oxford: Blackwell.

Shaw, M. (2002). Tougher line on overseas staff. Retrieved November 2, 2002, from http://www.tes.co.uk

Shepherd, R. (1997). Formative assessment for substitute teachers. The Clearing House, 71(2), 117-119.

Smithers, R., \& McGreal, C. (2001, February 16, 2001). 'Raid' on South African teachers. The Guardian.

Soucek, V. (1994). Flexible education and new standards of communicating competence. In J. Kenway (Ed.), Economising education: Post-Fordist directions. Geelong, Australia: Deakin University Press.

Spencer, S. (2002). Recent changes and future prospects in UK migration policy. Paper presented at the The Ladenburger Discourse on Migration, Ladenburger.

Tannenbaum, M. D. (2000). No substitute for quality. Educational Leadership(May), 7074.

Thomton, K. (2001). Agency frustrates Berkshire efforts. Retrieved November 2, 2002, from http://www.tes.co.uk

Wallace, W. (2004, December 03). Who pays the poacher's bill? Teachers Education Supplement.

Weems, L. (2003). Representations of substitute teachers and the paradoxes of professionalism. Journal of Teacher Education, 54(3), 254-265.

Woodward, K. (1997). Feminist critiques of social policy. In M. Lavalette \& A. Pratt (Eds.), Social Policy: A conceptual and theoretical introduction. California: Sage Publications.

Young, B. (1999). Is it just a matter of time? Part-time teaching employment in Alberta. In T. W. Harrison \& J. L. Kachur (Eds.), Contested Schools: Education, globalization, and democracy in Alberta (pp. 139-142).

Young, B. (2002). The "Alberta advantage": "DeKleining" career prospects for women educators. In C. Reynolds (Ed.), Women and School Leadership: International Perspectives (pp. 75-92). Albany, NY: SUNY Press.

Young, B., \& Grieve, K. (1996). Negotiating time: Reduced work employment arrangements for teachers. Paper presented at the Annual Meeting of the American Educational Research Association, New York: NY.

Katina Pollock is currently a Doctoral Candidate in the Theory and Policy Studies Department at Ontario Institute for Studies in Education/University of Toronto. She will be taking up a position as Assistant Professor at the University of Western Ontario in January of 2008. Her research interests include alternative work practices, contingent workforces, the teaching workforce, leadership, policy, equity and gender in teaching. 